The Birth of Landscape Painting in China 



\section{The Birth of}

\section{Landscape Painting in China}

\section{By Michael Sullivan}

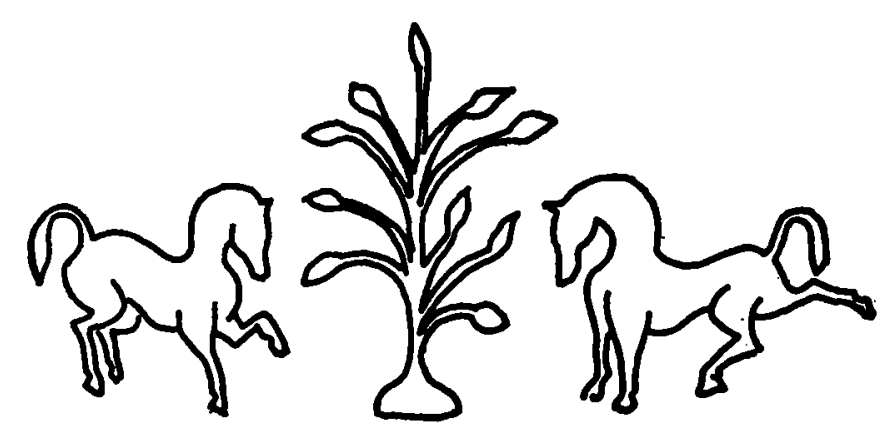

UNIVERSITY OF CALIFORNIA PRESS Berkeley and Los Angeles 
UNIVERSITY OF CALIFORNIA PRES Berkeley and Los Angeles, California

(C) 1962 BY MichaEL SULLIVAN

Library of Congress Catalog Card Number: 60-16863 Printed in the United States of America

Designed by Rita Carroll 
To KHOAN 
